\title{
Seasonal changes and diversity of aerobic anoxygenic phototrophs in the Baltic Sea
}

\author{
Michal Mašín ${ }^{1,2}$, Agnieszka Zdun ${ }^{3}$, Joanna Stoń-Egiert' ${ }^{3}$, Monika Nausch $^{4}$, \\ Matthias Labrenz ${ }^{4}$, Vladimíra Moulisová ${ }^{2}$, Michal Koblížek ${ }^{1,2, *}$
}

\author{
${ }^{1}$ Institute of Physical Biology, Zámek 136, 37333 Nové Hrady, Czech Republic \\ ${ }^{2}$ Department of Autotrophic Microorganisms, Institute of Microbiology CAS, Opatovický mlýn, 37981 Třeboň, Czech Republic \\ ${ }^{3}$ Institute of Oceanology PAN, Powstańców Warszawy 55, 81-712 Sopot, Poland \\ ${ }^{4}$ Institut für Ostseeforschung, Warnemünde, Seestrasse 15, 18119 Rostock-Warnemünde, Germany
}

\begin{abstract}
The community of aerobic anoxygenic phototrophs was investigated in the Baltic Sea using infrared epifluorescence microscopy from September 2004 to October 2005. The majority of these bacteriochlorophyll-containing organisms exhibited a specific sickle-shaped morphology, with rods or other morphotypes observed only occasionally. Aerobic anoxygenic phototrophs were observed mostly from April to September (1 to $12 \%$ of total prokaryotes), peaking in May 2005 at a concentration of up to $0.38 \times 10^{6} \mathrm{cells} \mathrm{ml}^{-1}$. This peak was associated with the later phase of the spring bloom. In the later months, the amount of phototrophic bacteria gradually declined until the beginning of the fall mixing, and remained low from November to March, contributing only 0 to $2 \%$ of total prokaryotes. A novel technique combining fluorescent in situ hybridization (FISH) and infrared epifluorescence microscopy indicated that the Baltic aerobic anoxygenic phototrophs were mostly Gammaproteobacteria, with a smaller fraction of Alphaproteobacteria.
\end{abstract}

KEY WORDS: Aerobic photosynthetic bacteria - Bacteriochlorophyll a P Photoheterotrophy · Epifluorescence microscopy

Resale or republication not permitted without written consent of the publisher

\section{INTRODUCTION}

Bacteria containing bacteriochlorophyll a (Bchl a) were recently found to account for a significant fraction of the microbial community in the upper ocean (Kolber et al. 2000, 2001). These organisms, called aerobic anoxygenic phototrophs (AAPs), perform photoheterotrophic metabolism based on an obligatory supply of organic substrates for growth, but derive a significant portion of their energy requirements from light (Koblížek et al. 2003, Rathgeber et al. 2004). The ability to utilize light energy appears to offer an ecological advantage serving as an auxiliary source of ATP. The presence of these bacteria was confirmed in various marine environments using genetic (Béjà et al. 2002, Du et al. 2005, Oz et al. 2005) and pigment analyses (Goericke 2002), epifluorescence microscopy (Schwalbach \& Fuhrman 2005, Cottrell et al. 2006, Sieracki et al. 2006), as well as infrared (IR) kinetic flu- orometry (Koblížek et al. 2005, 2006). In spite of that, knowledge of the distribution, diversity, and ecological roles of AAPs in marine environments remains only fragmentary.

The Baltic Sea is a brackish, rather heterogeneous, enclosed-shelf sea system (Omstedt et al. 2004). The plankton dynamics of the Baltic Sea are characterized by 2 seasonal blooms. The spring bloom (March-May) is typically dominated by dinophytes and/or diatoms ( 80 to $95 \%$ of the total biomass) with a minority of chlorophytes, cryptophytes, and cyanobacteria. During early summer, a 3-layer stratification is formed, with a stable thermocline at 20 to $25 \mathrm{~m}$ and a permanent halocline at 50 to $60 \mathrm{~m}$. Temperatures above the thermocline typically range from 15 to $18^{\circ} \mathrm{C}$. Occasionally, intensive solar heating coupled with prolonged periods of calm weather triggers the formation of an additional thin warm surface layer $\left(>20\right.$ to $22^{\circ} \mathrm{C}$ ) extending to depths of 2 to $4 \mathrm{~m}$. Beginning in late September, the 
thermocline structure gradually dissolves due to the decrease in irradiance and intensified wind mixing. The autumn bloom (September-October) is dominated by cyanobacteria along with dinophytes and chlorophytes as other main contributors (Stoń et al. 2002, Wasmund \& Uhlig 2003). By the end of the fall season, the water column becomes homogenous down to the halocline, with mean water temperatures of 3 to $4^{\circ} \mathrm{C}$.

Earlier studies suggested that Baltic primary production is mostly limited by nitrogen availability, but the activity of nitrogen-fixing cyanobacteria in the summer period may cause limitation by phosphorus (Kivi et al. 1993, Nausch et al. 2004). Knowledge of Baltic bacterioplankton dynamics pattern is fragmentary. In the coastal zone offshore of Sweden, bacterial cell numbers display a relatively simple pattern, with a minimum in winter and a maximum in summer (Hagström et al. 1979). In early spring, the bacterial community is predominantly controlled by nitrogen availability and nanoflagellate grazing (Kuupo et al. 1998). In some studies, a stimulation of bacterial growth by phosphorus was observed in late spring, whereas in summer a great stimulation was induced by the combined addition of nitrogen and phosphorus (Kivi et al. 1993).

In a previous study, we surveyed the presence of AAPs in the Baltic Sea in late summer (August-September) 2003 by IR kinetic fluorometry; at that time, Bchl a concentration varied between 8 and $50 \mathrm{ng} \mathrm{l}^{-1}$ (Koblížek et al. 2005). Interestingly, during our next survey in April 2004, the activity of AAPs was below the detection limit of the instrument ( 2 ng Bchl a $\mathrm{l}^{-1}$; M. Koblížek unpubl. data). This result suggested that the community of AAPs in the Baltic Sea undergoes seasonal changes. For this reason, we followed the changes of the AAP community in the Baltic Sea during the whole year. For analyses of the microbial communities, we employed the IR-epifluorescence microscopy technique as it offers direct information on AAP abundance together with very high sensitivity.

\section{MATERIALS AND METHODS}

Sampling. Samples were collected from a number of stations in the southern Baltic Sea (see Table 1). All stations were more than 5 nautical miles offshore. Water samples were collected in Niskin bottles, fixed with $2 \%$ formaldehyde $(0.2 \mu \mathrm{m}$ prefiltered $)$, gently mixed, incubated at room temperature for $60 \mathrm{~min}$, and then stored in a freezer at $-20^{\circ} \mathrm{C}$. The samples were shipped in a frozen state and analyzed in the Třeboň laboratory, typically within 1 mo after sample collection. As tested with Roseobacter-like strain COL2P (Rontani et al. 2005), the freeze-thaw cycle of formaldehyde-fixed samples does not significantly reduce their IR emission. Chlorophyll a ( chl a) content was determined by high performance liquid chromatography as described previously (Koblížek et al. 2005) or spectrophotometrically in $90 \%$ acetone extracts.

Microscopy. Thawed and gently mixed water samples were collected onto $0.2 \mu \mathrm{m}$ polycarbonate filters, dried, and stained with 4', 6-diamidino-2-phenylindole (DAPI) using a 3:1 mixture of Citifluor ${ }^{\mathrm{TM}} \mathrm{AF} 1$ and Vectashield $^{\circledR}$ containing $1 \mathrm{ng} \mathrm{ml}{ }^{-1}$ DAPI. The reduced DAPI concentration was used to avoid DAPI fluorescence interference (cross-talk) with other measured channels and to enhance the contrast between the objects and the background. The number of steps during sample staining was reduced to prevent bacterial losses due to washing. Epifluorescence microscopy was performed using an Olympus BX51TF fluorescence microscope equipped with an Olympus Universal Planapochromat 100×/1.35 OIL, IR objective. Illumination was provided by a 100W USH-103OL USHIO mercury lamp. Fluorescence images were recorded with a B/W CCD camera F-ViewII. For the IR epifluorescence, we used a custom filter setup: excitation $<700 \mathrm{~nm}$ dichroic filter, $680 \mathrm{~nm}$ dichroic mirror (Photon Systems Instruments) and emission $>850 \mathrm{~nm}$ glass filter (Oriel 51360). First, the total DAPI-stained bacteria were recorded in the blue part of the spectrum (100-200 ms exposure). Then, IR emission image was captured, showing both AAPs and phytoplankton (15 to $35 \mathrm{~s}$ exposition). Finally, red chl a autofluorescence was recorded to identify chl a-containing organisms ( 0.5 to $1 \mathrm{~s}$ exposition). The acquired images were saved and semi-manually analyzed with the aid of AnalySiS software (Soft Imaging Systems). The individual images were artificially colored (DAPI: blue; chl a: green; IR: red) and overlayed to create a composite image. The composite image allowed us to distinguish the Bchl $a$ - and chl a-containing microorganisms and to obtain net counts of heterotrophic bacteria, picocyanobacteria, and AAPs for each sample. The objects were counted manually to avoid problems with automatic assessment. For each individual sample, 8 to 12 frames were recorded and analyzed ( 400 to 600 DAPI cells).

The procedure described above was tested to successfully visualize laboratory cultures of Erythrobacter sp. NAP1 and Roseobacter-like strain COL2P containing 30 to $120 \mathrm{ag} \mathrm{Bchl} a$ per cell. This pigment content corresponds to numbers reported for AAP communities in the northeastern Pacific (Kolber et al. 2001) and thus can be interpreted as environmentally relevant.

Fluorescent in situ hybridization. For the phylogenetic affiliation of individual AAP cells, a combination of IR epifluorescence microscopy and fluorescent in situ hybridization (FISH) was used. The main bacterioplankton groups were targeted using ALF1B, BET42a, 
GAM42a, and EUB338 probes marked by Cy3 fluorophore on the $5^{\prime}$-end (Manz et al. 1992). We also employed a specific probe for the Sphingomonas/ Erythrobacter clade (sequence: TAGCCGGAGCTT ATTCTC; competitor: TAGCCGGAGCTTATTCTG; Helpers: H433 - ATCCCKGGTAAAAGAGC, H450 CMGRTACTGTCATTATC, H510 - CGGCTGCTGGCACGGAGT, H528 - CTAGCTCCCTCCGTATTACCG), using $20 \%$ formamide concentration.

The standard FISH protocol (Manz et al. 1992, Mašín et al. 2003) was modified as follows: the hybridization time was prolonged to $180 \mathrm{~min}$, and the final ethanol drying was omitted to prevent Bchl a degradation in the samples. The assignment of bacteria to individual proteobacterial groups was done based on fluorescent oligonucleotide probe signals for each individual probe, and the AAPs were then identified in the IR region. In this way, we prevented the bleaching of FISH fluorophores by the long light exposure used to acquire the IR image. Due to some Bchl a loss caused by the longer sample preparation and the subsequent washing and heating steps, it was necessary to use even longer exposures $(\sim 35 \mathrm{~s})$ to acquire the IR images than in normal samples. The evaluation of positively hybridized cells was similar to the analysis of Bchl acontaining bacteria. The image was saved, artificially colored (yellow), and added to the composite image as the fourth channel. By this approach, we eliminated potential errors caused by spectrally close emission of chl $a$ and Cy3. The percentage of individual proteobacterial groups was expressed as a percentage of total AAPs.

\section{RESULTS}

The composition of the Baltic microbial community was analyzed by IR epifluorescence microscopy. The most frequent morphotype of AAPs observed throughout the year was a sickle-shaped cell with average dimensions of $2.27 \pm 0.48 \mu \mathrm{m}$ (Fig. 1). Other morphotypes were occasionally observed, e.g. rod-shaped cells with average dimensions $2.33 \pm 0.30 \mu \mathrm{m}$ (Fig. 1) or large S-shaped cells. Similarly to cyanobacteria, AAPs were found in the euphotic part of the water column, which is consistent with their ability to utilize light (Fig. 2).

The seasonal changes of the Baltic microbial community were studied in the period from September 2004 to October 2005. Samples were collected from the surface layer at several stations in the southern part of the Baltic Sea (Table 1). During the period studied, the microbial community in the Baltic displayed large changes (Fig. 3). In September 2004, AAPs accounted for approximately $3 \%$ of total prokaryotes (DAPI) in

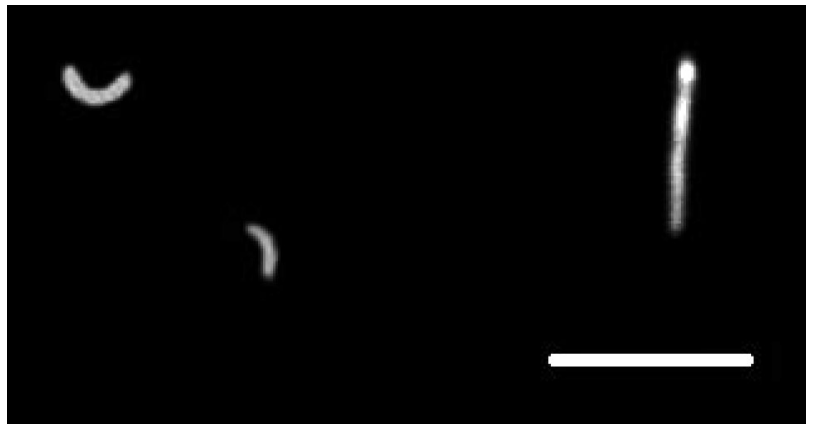

Fig. 1. Composite microscopic image showing infrared autofluorescence of the most abundant aerobic anoxygenic phototroph (AAP) morphotypes observed in the Baltic Sea. The sample was collected on 10 July 2005 at Stn 271, Gotland Deep. Scale bar $=5 \mu \mathrm{m}$

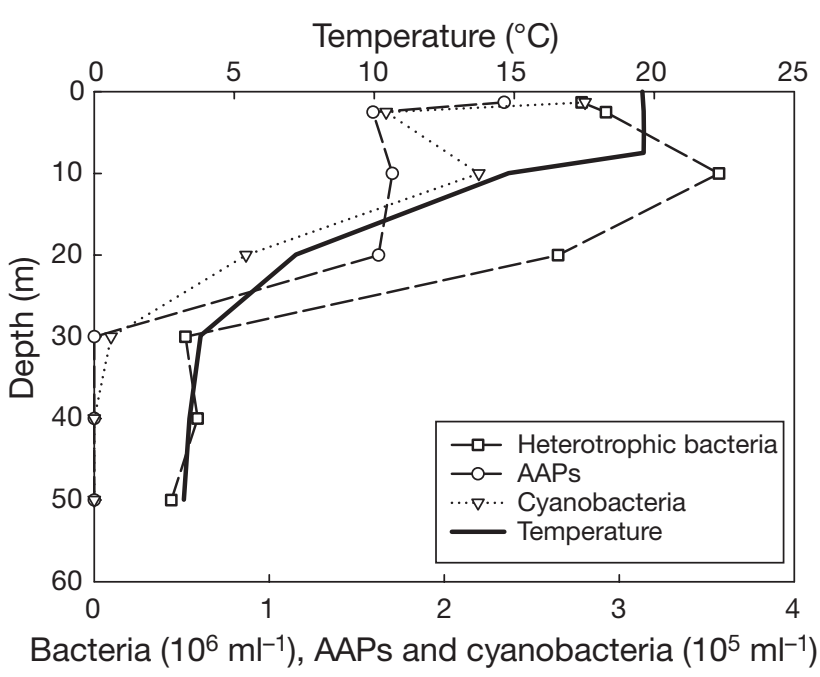

Fig. 2. Vertical profile of the microbial community composition at Stn 271, Gotland Deep, on 10 July 2005. Number of total DAPI-stained bacteria, picocyanobacteria, and AAPs were assessed as described in the 'Materials and methods'

the open southern Baltic, whereas in the Bay of Gdańsk, AAPs accounted for only $1 \%$. The progression of mixing in October caused the autumn phytoplankton bloom, whereas the relative abundance of AAPs declined to 1 to $2 \%$. The abundance of AAPs was low during the whole winter period from November to March $(<1 \%)$. The spring bloom started in the southern part of the Bay of Gdańsk in March and progressed north, reaching the peak of chlorophyll concentration in April. In contrast, the numbers of heterotrophic bacteria as well as AAPs increased only slightly. In May, the chlorophyll concentration declined somewhat, whereas AAP abundance increased to their absolute maximum of $0.38 \times 10^{6}$ cells ml $^{-1}$, contributing up to $12 \%$ of the bacterial community. This indicates that the AAP peak was related to the later phase of the 
Table 1. Stations surveyed from September 2004 to October 2005. Areas: AB, Arkona Basin; BB, Bornholm Basin; GB, Gdańsk Basin; BG, Bay of Gdańsk; EGB, Eastern Gotland Basin. Depth describes the depth of the sea at a particular station

\begin{tabular}{|c|c|c|c|c|c|c|c|c|c|c|c|c|c|c|}
\hline Stn & Area & Depth (m) & Lat $\mathrm{N}$ & Lon E & Sep & Oct & Nov & Jan & Mar & Apr & May & Jul & Sep & Oct \\
\hline P115 & BG & 57 & $54^{\circ} 26.2^{\prime}$ & $19^{\circ} 02.5^{\prime}$ & $x$ & $\times$ & & $x$ & $x$ & $\times$ & $x$ & & & \\
\hline P110 & BG & 70 & $54^{\circ} 30^{\prime}$ & $19^{\circ} 06.8^{\prime}$ & $x$ & $x$ & & $x$ & & $x$ & $x$ & & $x$ & \\
\hline P104b & BG & 84 & $54^{\circ} 35^{\prime}$ & $19^{\circ} 12.5^{\prime}$ & $x$ & $x$ & & $x$ & & $x$ & $x$ & & $x$ & \\
\hline P116 & BG & 88 & $54^{\circ} 39^{\prime}$ & $19^{\circ} 17.6^{\prime}$ & $x$ & $x$ & $x$ & & & $x$ & & & $x$ & \\
\hline P1 & GB, Gdańsk Deep & 112 & $54^{\circ} 50^{\prime}$ & $19^{\circ} 20^{\prime}$ & & $x$ & $x$ & $x$ & $x$ & $x$ & $x$ & & & \\
\hline $\mathrm{P} 2$ & EGB & 76 & $55^{\circ} 18^{\prime}$ & $18^{\circ} 00^{\prime}$ & & & & $x$ & $x$ & $x$ & & & & \\
\hline P3 & $\mathrm{BB}$ & 92 & $55^{\circ} 12^{\prime}$ & $17^{\circ} 04^{\prime}$ & & & & $x$ & & $x$ & & & & \\
\hline $\mathrm{P} 2 \mathrm{a}$ & EGB & 80 & $55^{\circ} 16^{\prime}$ & $17^{\circ} 42^{\prime}$ & $x$ & & & & & & & & & \\
\hline $\mathrm{P} 2 \mathrm{~b}$ & $\mathrm{BB}$ & 90 & $55^{\circ} 15^{\prime}$ & $17^{\circ} 24^{\prime}$ & $x$ & & & & & & & & & \\
\hline $\mathrm{P} 3 \mathrm{C}$ & $\mathrm{BB}$ & 55 & $55^{\circ} 14^{\prime}$ & $16^{\circ} 30^{\prime}$ & $\times$ & & & & & & & & & \\
\hline P3d & $\mathrm{BB}$ & 65 & $55^{\circ} 15^{\prime}$ & $16^{\circ} 21^{\prime}$ & $x$ & & & & & & & & & \\
\hline P3e & $\mathrm{BB}$ & 78 & $55^{\circ} 14^{\prime}$ & $16^{\circ} 12^{\prime}$ & $x$ & & & & & & & & & \\
\hline P3f & $\mathrm{BB}$ & 89 & $55^{\circ} 15^{\prime}$ & $16^{\circ} 00^{\prime}$ & $x$ & & & & & & & & & \\
\hline Born1 & $\mathrm{BB}$ & 60 & $55^{\circ} 15^{\prime}$ & $15^{\circ} 05^{\prime}$ & $\times$ & & & & & & & & & \\
\hline ZP30 & $\mathrm{BB}$ & 35 & $54^{\circ} 41^{\prime}$ & $14^{\circ} 44^{\prime}$ & & $\times$ & & & & & & & & \\
\hline ZP32 & $\mathrm{BB}$ & 15 & $54^{\circ} 32.6^{\prime}$ & $14^{\circ} 39.2^{\prime}$ & & $\times$ & & & & & & & & \\
\hline ZP34 & $\mathrm{BB}$ & 15 & $54^{\circ} 25.2^{\prime}$ & $14^{\circ} 39.4^{\prime}$ & & $\times$ & & & & & & & & \\
\hline ZP36 & $\mathrm{BB}$ & 8 & $54^{\circ} 16.8^{\prime}$ & $14^{\circ} 29.2^{\prime}$ & & $\hat{x}$ & & & & & & & & \\
\hline ZP38 & $\mathrm{BB}$ & 12 & $54^{\circ} 07.2^{\prime}$ & $14^{\circ} 23.2^{\prime}$ & & $\hat{x}$ & & & & & & & & \\
\hline MK1 & $\mathrm{BG}$ & 35 & $54^{\circ} 33.4^{\prime}$ & $18^{\circ} 41.9^{\prime}$ & & & $x$ & & & & & & & \\
\hline P40 & EGB & 100 & $55^{\circ} 38^{\prime}$ & $18^{\circ} 36^{\prime}$ & & & & $x$ & & & & & & \\
\hline P63 & EGB & 82 & $55^{\circ} 21.1^{\prime}$ & $19^{\circ} 03.2^{\prime}$ & & & & & $x$ & & & & & \\
\hline R6 & GB & 27 & $54^{\circ} 57.3^{\prime}$ & $18^{\circ} 25^{\prime}$ & & & & & $x$ & & & & & \\
\hline $\mathrm{R} 8$ & GB & 70 & $55^{\circ} 07.9^{\prime}$ & $18^{\circ} 11.9^{\prime}$ & & & & & $x$ & & & & & \\
\hline Jola4 & GB & 105 & $54^{\circ} 54^{\prime}$ & $19^{\circ} 18^{\prime}$ & & & & & & & $x$ & & & \\
\hline Jola7 & GB & 85 & $55^{\circ} 13^{\prime}$ & $19^{\circ} 18^{\prime}$ & & & & & & & $x$ & & & \\
\hline Jola6 & GB & 90 & $55^{\circ} 25^{\prime}$ & $19^{\circ} 18^{\prime}$ & & & & & & & $x$ & & & \\
\hline 271 & EGB, Gotland Deep & 239 & $57^{\circ} 19.1^{\prime}$ & $20^{\circ} 03.6^{\prime}$ & & & & & & & & $x$ & & $x$ \\
\hline L1 & EGB & 73 & $57^{\circ} 49.5^{\prime}$ & $21^{\circ} 21.2^{\prime}$ & & & & & & & & $x$ & & \\
\hline 259 & EGB & 94 & $55^{\circ} 33.1^{\prime}$ & $18^{\circ} 24.3^{\prime}$ & & & & & & & & $x$ & & \\
\hline 213 & $\mathrm{BB}$ & 95 & $55^{\circ} 15^{\prime}$ & $15^{\circ} 59^{\prime}$ & & & & & & & & $x$ & & $\times$ \\
\hline 113 & $\mathrm{AB}$ & 44 & $54^{\circ} 55.4^{\prime}$ & $13^{\circ} 29.8^{\prime}$ & & & & & & & & & & $\times$ \\
\hline
\end{tabular}

spring phytoplankton bloom, which had started 1 mo earlier. In July, the numbers of heterotrophic bacteria reached their maxima, and although the absolute AAP abundance remained high, their relative presence within the microbial community decreased. Finally, in September and October 2005, AAP numbers gradually declined concomitantly with reduced solar radiation and decreased water temperature.

Over the whole annual cycle, the absolute abundance of AAPs was weakly positively correlated with chlorophyll concentration $\left(r^{2}=0.19, n=91\right.$, Fig. 4). However, there was no relationship between chlorophyll concentration and AAP abundance when expressed as a percentage of total prokaryotes (not shown). Despite the lack of a general relationship between the relative AAP abundance ( $\%$ of total prokaryotes) and chlorophyll, we did observe an increase in the percentage of AAPs along a transect from the Wisła (Vistula) estuary towards the open sea. This trend was most visible in April 2005, when a steep chl a gradient (from 33 to $6 \mathrm{mg} \mathrm{m}^{-3}$ ) had been formed between the Bay of Gdańsk and the open sea (Fig. 5). The same trend with lower AAP percentage in the bay and higher numbers in the open sea was also recorded in September 2004, although the chlorophyll gradient was less steep.

Interestingly, the seasonal changes in the numbers of heterotrophic bacteria displayed a strong temperature dependence with an almost linear relationship in the range from 2 to $20^{\circ} \mathrm{C}\left(\mathrm{r}^{2}=0.71, \mathrm{n}=102\right.$, Fig. $\left.6 \mathrm{~A}\right)$, while the chl a concentration was independent of temperature. The temperature dependence of AAP numbers was weak, falling somewhere in between these limiting cases (linear relationship $r^{2}=0.21$ ), which is in line with their dual character placing them between purely heterotrophic bacteria and photoautotrophic organisms.

The diversity of the AAP community was studied using the FISH technique. The analysis performed on samples collected in July and October 2005 at Stn 271 (Gotland Deep) indicated that the AAP population was dominated by Gammaproteobacteria (70 to $75 \%$ ), with a smaller (20 to $27 \%$ ) fraction of Alphaproteobacteria (Fig. 7). Gammaproteobacteria were characterized by sickle-shaped cells, whereas Alphaproteobacteria were rather diverse, displaying sickle-shaped, rod- 

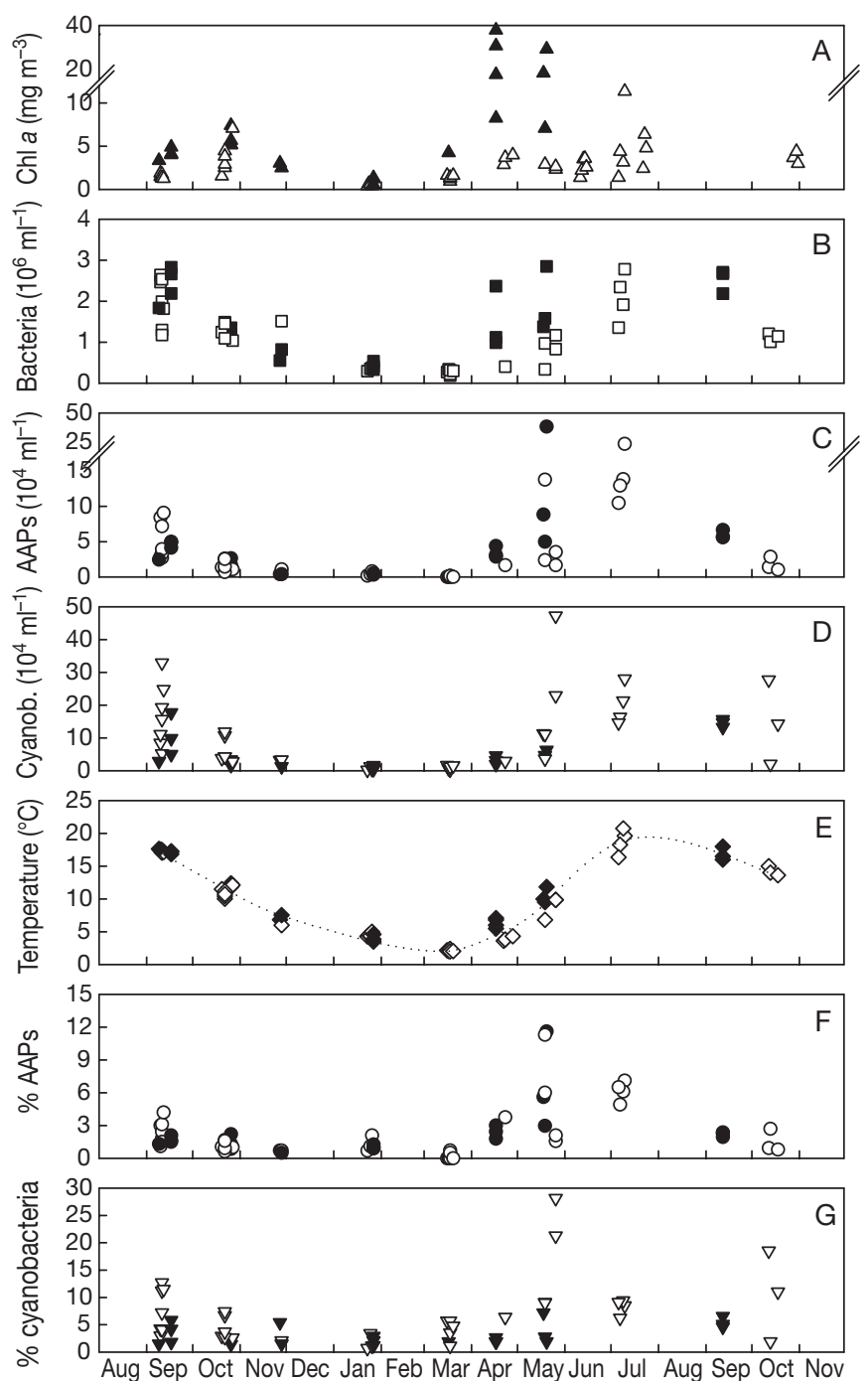

Month

Fig. 3. Seasonal changes in (A) chl a concentration, (B) heterotrophic bacteria (total DAPI counts minus cyanobacteria and AAPs), (C) AAPs, (D) picocyanobacteria, and (E) water temperature in the surface layer over the southern Baltic from September 2004 to October 2005. Seasonal changes in (F) AAPs and (G) cyanobacteria are expressed as percentage of total DAPI-stained prokaryotes. Open symbols: samples obtained from the open sea; closed symbols: samples collected in the Bay of Gdańsk

shaped, and vibrioid morphologies. The presence of Erythrobacter-related species was confirmed by FISH in July, when this subgroup constituted approximately $18 \%$ of all visualized AAPs (i.e. approximately $60 \%$ of all AAPs belonging to Alphaproteobacteria). This group was composed of both sickle- and rod-shaped cells. Interestingly, AAPs formed only one-third of all cells positively hybridized with the Sphingomonas/ Erythrobacter probe. AAPs belonging to Betaproteobacteria were not observed.

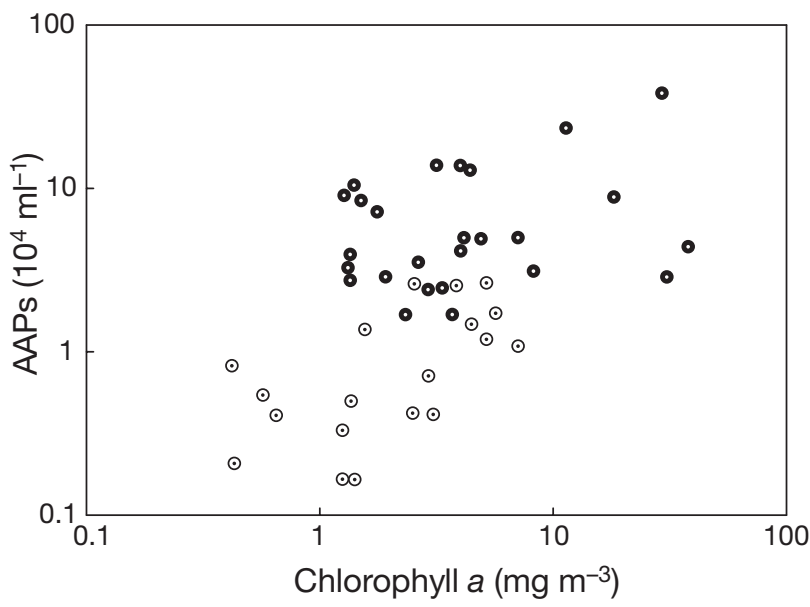

Fig. 4. Relationship between AAP cell numbers and chlorophyll concentration. ( $\odot$ ) Samples collected from October 2004 to March 2005; (•) Samples collected during the summer period (September 2004, April-September 2005)

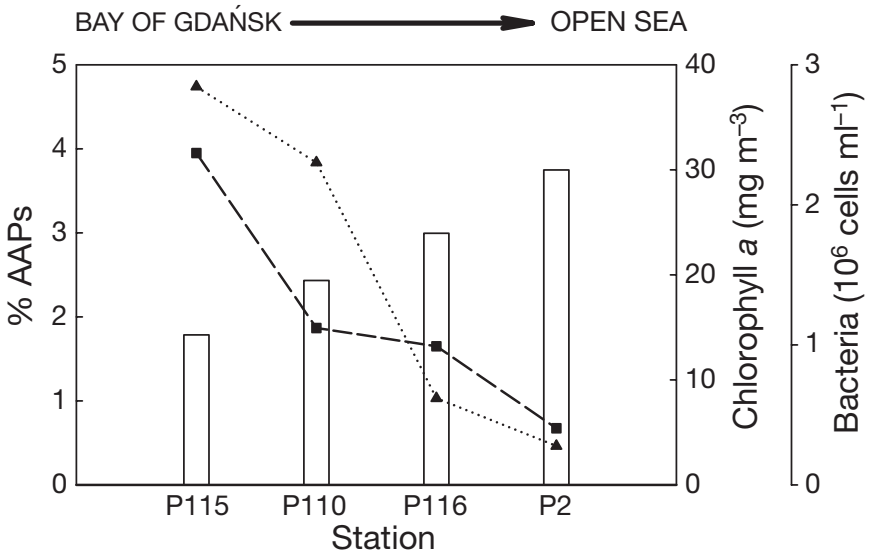

Fig. 5. Changes in relative AAP abundance (fraction of total prokaryotes, bars), heterotrophic bacteria, and chlorophyll concentration along a transect from the Bay of Gdańsk towards the open sea, determined in April 2005. (ロ) Heterotrophic bacteria; (ム) chlorophyll content

\section{DISCUSSION}

In their pioneering work, Kolber et al. (2000) hypothesized that AAPs are abundant mostly in oligotrophic environments. Since then, the presence of AAPs has been reported from the Baltic Sea (Koblížek et al. 2005), the Black Sea (Kobližek et al. 2006), and the Atlantic Ocean (Cottrell et al. 2006, Sieracki et al. 2006), which demonstrates that AAPs are rather widespread throughout various marine environments with different trophic status. AAP abundances are currently a matter of controversy. Kolber et al. (2001) reported that AAPs constitute up to $11 \%$ of the marine microbial community in oligotrophic waters of the northeastern 

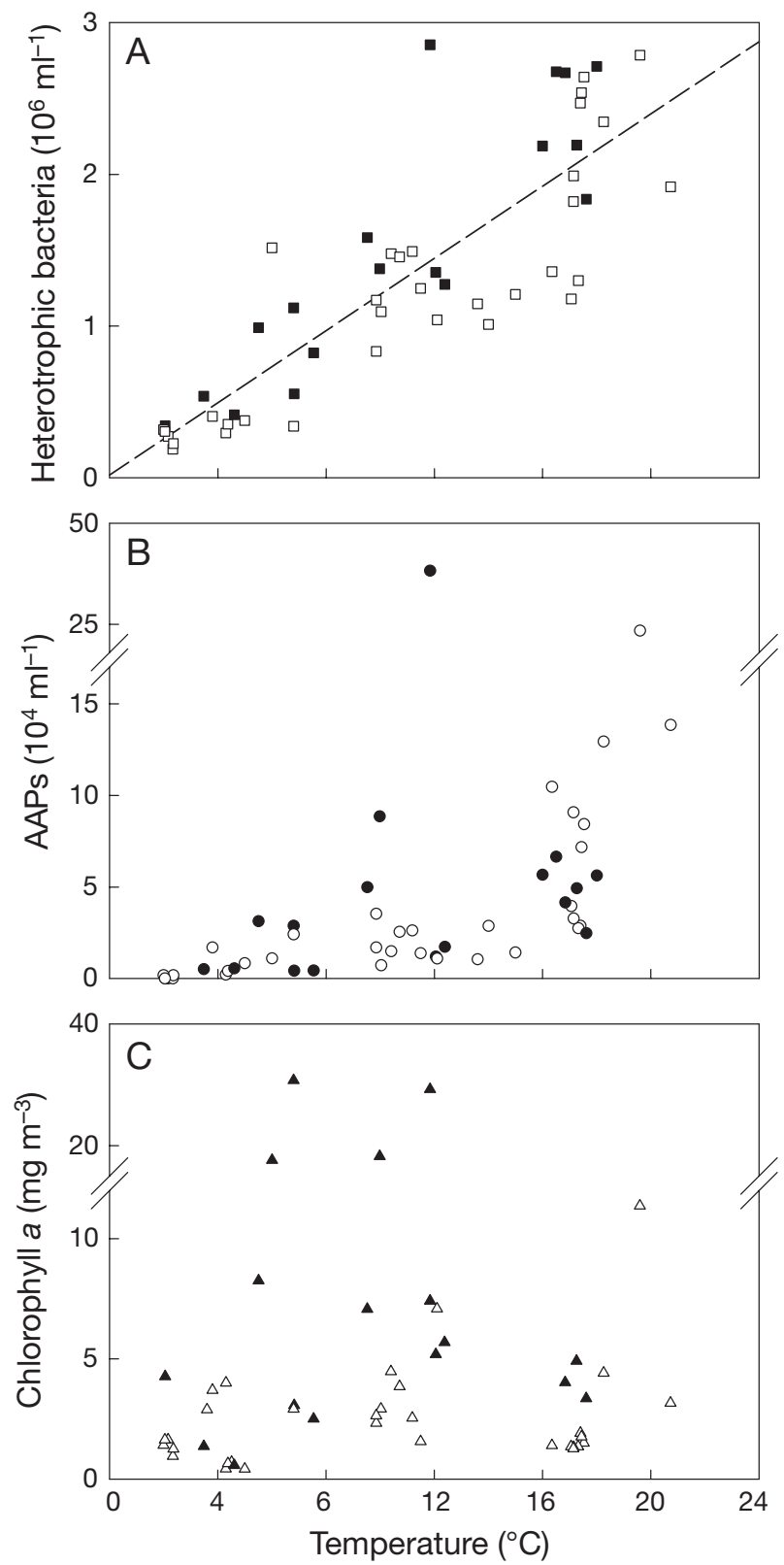

Fig. 6. (A) Temperature dependence of heterotrophic bacteria abundance (total DAPI counts minus cyanobacteria and AAPs), (B) AAP cell numbers and (C) chlorophyll concentration. Closed symbols: samples collected in the Bay of Gdańsk; open symbols: samples from the open sea stations

Pacific. Such high estimates of AAP abundance were questioned by Schwalbach \& Fuhrman (2005), who reported that AAPs comprised only 0.2 to $2.5 \%$ of total bacteria in the San Pedro Channel in southern California. Later, estimates of 5 to $15 \%$ (Cottrell et al. 2006) and 1 to $9 \%$ (Sieracki et al. 2006) were reported for the North Atlantic. These reports corroborate our observations in the summer period (April to September), when AAPs represented 1 to $12 \%$ of the total bacteria.

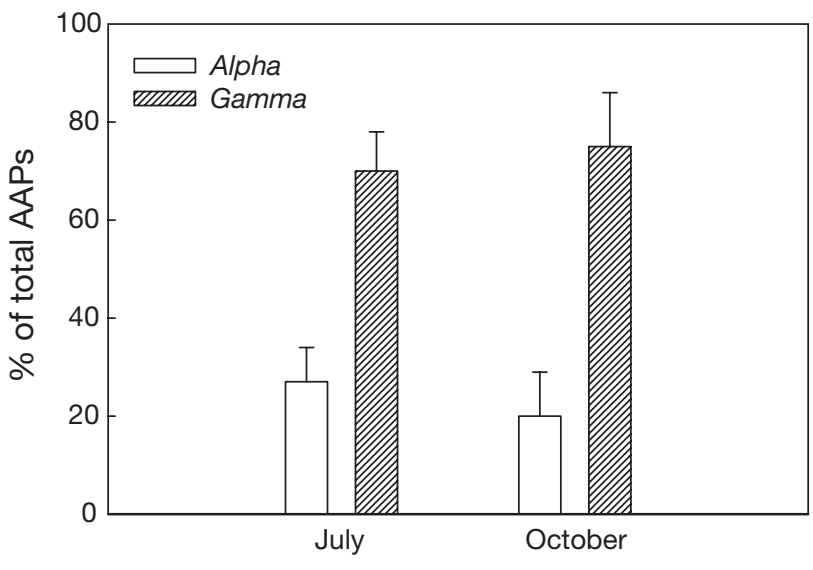

Fig. 7. AAP community composition at Stn 271, Gotland Deep, on 10 July and 13 October 2005, determined by a combination of FISH and IR epifluorescence microscopy. Contribution of individual groups is expressed as the fraction of total AAPs

IR microscopy has an advantage of providing direct information on the abundance of AAPs with very high sensitivity. AAPs are recognized based on their specific Bchl $a$ emission in the IR region (860 to $900 \mathrm{~nm}$ ). One potential drawback of the method is that the raw IR image also contains a contribution from the IR tail emission of the chl a-containing microorganisms. However, this problem can be easily corrected by subtraction of the chl a channel as discussed by Schwalbach \& Fuhrman (2005) and as was also done in the present study. Another problem is that the accurate quantification of AAPs depends critically on the quality of the charge-coupled device (CCD) camera used. Using an image-intensified CCD camera, Cottrell et al. (2006) were able to acquire IR images using acquisition times as short as $0.2 \mathrm{~s}$, which might explain the relatively higher AAP abundances reported in their study. The equipment used by Schwalbach \& Fuhrman (2005) has comparatively poor characteristics in the IR region, which forced the authors to use rather long (71 s) exposures to obtain measurable signals. In our setup, we typically used exposure times of 15 to $35 \mathrm{~s}$, which still resulted in some pigment bleaching and signal loss, especially in small cells. Therefore, the IR epifluorescence cell counts performed with very long exposure times must be interpreted carefully, as the numbers of Bchl a-containing cells may be underestimated.

Seasonal succession is one of the classical issues of plankton microbial ecology. The AAP community in the Baltic displayed a clear seasonal pattern, with the maximum in May and the minimum during winter. The abundance of the heterotrophic bacterial community displayed a simple pattern with the maximum in summer and the minimum in winter, following, at first approximation, the changes of temperature (Fig. 6). This observation is consistent with earlier studies 
reporting a relationship between temperature and bacterial activity in coastal and brackish seas (e.g. Hagström et al. 1979, Reinthaler \& Herndl 2005). In contrast, phytoplankton dynamics in mid latitudes are usually characterized by 2 seasonal blooms in spring and in fall. As AAPs possess characteristics of both heterotrophic bacteria (oxidative phosphorylation of dissolved organic matter) and phytoplankton (light-driven photophosphorylation; Harashima \& Takamiya 1989), the factors that determine AAP abundances are a combination of forcing factors affecting phototrophic and heterotrophic organisms. Similarly to phytoplankton, AAPs display a pronounced spring peak, but they operate with much smaller light-harvesting complexes (requiring higher light fluxes for photophosphorylation), resulting in an AAP bloom later in the season. Oxidative phosphorylation (respiration), on the other hand, is strongly dependent on temperature, reducing the AAP numbers during the winter period (low light conditions).

The diversity of AAPs is currently a matter of discussion. The initial claim that the AAP community is dominated by Erythrobacter sp. (Kolber et al. 2001) was later dismissed by both culture-free (Béjà et al. 2002) and cultivation studies (Rontani et al. 2005, Koblížek et al. 2006). Rontani et al. (2005) isolated 3 strains of Erythrobacter and Roseobacter species from the Baltic Sea, which confirms the presence of these genera in the environment. Cottrell et al. (2006) attempted to estimate AAP community composition in the MidAtlantic Bight by comparing cell numbers of AAPs with abundances of individual bacterial groups (Erythrobacter, Roseobacter) determined by FISH. The problem with this approach is that photoheterotrophs do not form separate clades, and closely related species (based on 16S rDNA) perform either photoheterotrophic or purely heterotrophic metabolism. Moreover, the potential contribution of Gammaproteobacteria was not taken into account. In our study, we used the combination of IR epifluorescence microscopy and FISH, where the presence of Bchl a and genetic affiliation are assessed in one assay. The results showed that Baltic AAPs were formed mostly by Gammaproteobacteria and smaller numbers of Alphaproteobacteria. This result agrees with molecular analysis of pufM sequences obtained from Monterey Bay (California, USA), which indicated that the AAP community was composed of Roseobacter-related species (Alpha-3 Proteobacteria) and as yet uncultivated Gammaproteobacteria (Béjà et al. 2002). In contrast, a recent study on AAP diversity from the Mediterranean and Red Seas revealed that local AAP communities were formed mostly by Roseobacter-like species (Oz et al. 2005). These results suggest that the composition of AAP communities varies among differ- ent environments, and the issue of AAP diversity clearly requires further research.

The majority of AAP cells displayed the sickle shaped morphology; this was observed among both Alpha- and Gammaproteobacteria. The same morphology of AAPs was also reported by Sieracki et al. (2006) from the Atlantic. Interestingly, none of our AAP isolates displayed this sickle-shaped morphology (M. Koblížek unpubl. data). These results show that the AAP community is rather diverse and suggest that the dominant AAPs are yet to be isolated.

In conclusion, our study in the Baltic Sea demonstrated that AAPs are also present in highly eutrophic marine environments. Their abundance displayed large seasonal changes, with the maximum in late spring and summer, while it remained low in winter months. The Baltic AAP community is rather heterogeneous, formed by both Alpha- and Gammaproteobacteria.

Acknowledgements. We thank the captains and crews of the RV 'Oceania' and the RV 'Professor Albrecht Penck'. We thank S. Sagan, P. Kowalczuk, and J. Beldowski for their assistance with the sample collection. This research was supported by Czech projects GAČR 204/05/0307, MŽP VAV SL1/6/04, GAAV 1QS500200570, Inst. research concepts MSM6007665808 and AV0Z50200510, and Czech-German bilateral project No. 436 TSE. Participation of M.M, V.M., and M.K. in the research cruises aboard RV 'Oceania' was supported by the EC 5th Framework Program project CeSSS No. EVK3-CT-2002-80004.

\section{LITERATURE CITED}

Béjà $\mathrm{O}$, Suzuki MT, Heidelberg JF, Nelson WC and 5 others (2002) Unsuspected diversity among marine aerobic anoxygenic phototrophs. Nature 415:630-633

Cottrell MT, Mannino A, Kirchman DL (2006) Aerobic anoxygenic phototrophic bacteria in the Mid-Atlantic Bight and the North Pacific Gyre. Appl Environ Microbiol 72: $557-564$

Du H, Jiao N, Hu Y, Zeng Y (2005) Real-Time PCR for quantification of aerobic anoxygenic phototrophic bacteria based on pufM gene in marine environment. J Exp Mar Biol Ecol 329:113-121

Goericke R (2002) Bacteriochlorophyll $a$ in the ocean: Is anoxygenic bacterial photosynthesis important? Limnol Oceanogr 47:290-295

Hagström Å, Larsson U, Hörstedt P, Normark S (1979) Frequency of dividing cells, a new approach to the determination of bacterial growth rates in aquatic environments. Appl Environ Microbiol 37:805-812

Harashima K, Takamiya KI (1989) Photosynthesis and photosynthetic apparatus. In: Harashima K, Shiba T, Murata N (eds) Aerobic photosynthetic bacteria. Japan Scientific Societies Press, Tokyo, p 39-72

Kivi K, Kaitala S, Kuosa H, Kuparinen J, Leskinen E, Lignell R, Marcussen B, Tamminen T (1993) Nutrient limitation and grazing control of the Baltic plankton during annual succession. Limnol Oceanogr 38:893-905 
Koblížek M, Béjà O, Bidigare RR, Christensen $\mathrm{S}$ and 5 others (2003) Isolation and characterization of Erythrobacter sp. strains from the upper ocean. Arch Microbiol 180:327-338

Koblížek M, Stoń-Egiert J, Sagan S, Kolber Z (2005) Diel changes in bacteriochlorophyll a concentration suggest rapid bacterioplankton cycling in the Baltic Sea. FEMS Microbiol Ecol 51:353-361

Koblížek M, Falkowski PG, Kolber ZS (2006) Diversity and distribution of photosynthetic bacteria in the Black Sea. Deep-Sea Res II 53:1934-1944

Kolber ZS, Van Dover CL, Niederman RA, Falkowski PG (2000) Bacterial photosynthesis in surface waters of the open ocean. Nature 407:177-179

Kolber ZS, Plumley FG, Lang AS, Beatty JT and 6 others (2001) Contribution of aerobic photoheterotrophic bacteria to the carbon cycle in the ocean. Science 292:2492-2495

Kuupo P, Autio R, Kuosa H, Setälä O, Tanskanen S (1998) Nitrogen, silicate and zooplankton control of the planktonic food-web in spring. Estuar Coast Shelf Sci 46:65-75

Manz W, Amann R, Ludwig W, Wagner M, Schleifer KH (1992) Phylogenetic oligodeoxynucleotide probes for the major subclasses of Proteobacteria: problems and solutions. Syst Appl Microbiol 15:593-600

Mašín M, Šimek $K$, Jezbera J, Nedoma J, Straškrabová V, Hejzlar J (2003) Changes in bacterial community composition and microbial activities along the longitudinal axis of two differently loaded canyon-shaped reservoirs. Hydrobiologia 504:99-113

Nausch M, Nausch G, Wasmund N (2004) Phosphorus dynamics during the transition from nitrogen to phosphate limitation in the central Baltic Sea. Mar Ecol Prog Ser 266: $15-25$

Editorial responsibility: Hugh MacIntyre, Dauphin Island, Alabama, USA
Omstedt A, Elken J, Lehmann A, Piechura J (2004) Knowledge of the Baltic Sea physics gained during the BALTEX and related programmes. Prog Oceanogr 63:1-28

Oz A, Sabehi G, Koblížek M, Massana R, Béjà O (2005) Roseobacter-like bacteria in Red and Mediterranean Sea aerobic anoxygenic photosynthetic populations. Appl Environ Microbiol 71:344-353

Rathgeber C, Beatty JT, Yurkov V (2004) Aerobic phototrophic bacteria: new evidence for the diversity, ecological importance and applied potential of this previously overlooked group. Photosynth Res 81:113-128

Reinthaler T, Herndl GJ (2005) Seasonal dynamics of bacterial growth efficiencies in relation to phytoplankton in the southern North Sea. Aquat Microb Ecol 39:7-16

Rontani JF, Christodoulou S, Koblížek M (2005) GC-MS structural characterization of fatty acids from marine aerobic anoxygenic phototrophic bacteria. Lipids 40: 97-108

Schwalbach MS, Fuhrman JA (2005) Wide-ranging abundances of aerobic anoxygenic phototrophic bacteria in the world ocean revealed by epifluorescence microscopy and quantitative PCR. Limnol Oceanogr 50:620-628

Sieracki ME, Gilg IC, Thier EC, Poulton NJ, Goericke R (2006) Distribution of planktonic aerobic anoxygenic photoheterotrophic bacteria in the northwest Atlantic. Limnol Oceanogr 51:38-46

Stoń J, Kosakowska A, Lotocka M, Lysiak-Pastuszak E (2002) Pigment composition in relation to phytoplankton community structure and nutrient content in the Baltic Sea. Oceanologia 44:419-437

Wasmund N, Uhlig S (2003) Phytoplankton trends in the Baltic Sea. ICES J Mar Sci 60:177-186

Submitted: June 2, 2006; Accepted: October 10, 2006

Proofs received from author(s): November 29, 2006 